\title{
Proteome-level display by 2-dimensional chromatography of extracellular matrix-dependent modulation of the phenotype of bladder cancer cells
}

\author{
Robert E Hurst*1,2,3, Kimberly D Kyker ${ }^{1}$, Mikhail G Dozmorov¹, \\ Nobuaki Takemori², Anil Singh ${ }^{2}$, Hiroyuki Matsumoto ${ }^{2}$, Ricardo Saban ${ }^{4}$, \\ Edna Betgovargez ${ }^{5}$ and Michael H Simonian ${ }^{5}$
}

\begin{abstract}
Address: ${ }^{1}$ Department of Urology, Oklahoma University Health Sciences Centre, Oklahoma City, OK 73104, USA, ${ }^{2}$ Department of Biochemistry and Molecular Biology, Oklahoma University Health Sciences Centre, Oklahoma City, OK 73104, USA, ${ }^{3}$ Department of Occupational and Environmental Health, Oklahoma University Health Sciences Centre, Oklahoma City, OK 73104, USA, ${ }^{4}$ Department of Physiology, Oklahoma University Health Sciences Centre, Oklahoma City, OK 73104, USA and ${ }^{5}$ Biomedical Research Division, Beckman Coulter Inc. 4300 N. Harbor Blvd., Fullerton, CA 92834, USA

Email: Robert E Hurst* - Robert-hurst@ouhsc.edu; Kimberly D Kyker - Kimberly-Kyker@ouhsc.edu; Mikhail G Dozmorov - MikhailDozmorov@ouhsc.edu; Nobuaki Takemori - nobuaki-takemori@ouhsc.edu; Anil Singh - anil-singh@ouhsc.edu; Hiroyuki Matsumoto - hiroyuki-matsumoto@ouhsc.edu; Ricardo Saban - Ricardo-Saban@ouhsc.edu; Edna Betgovargez - ebetgovargez@beckman.com; Michael H Simonian - mhsimonian@beckman.com

* Corresponding author
\end{abstract}

Published: 02 June 2006

Proteome Science 2006, 4:13 doi:10.1 | 86//477-5956-4-13
Received: 30 November 2005

Accepted: 02 June 2006

This article is available from: http://www.proteomesci.com/content/4/1/13

(C) 2006 Hurst et al; licensee BioMed Central Ltd.

This is an Open Access article distributed under the terms of the Creative Commons Attribution License (http://creativecommons.org/licenses/by/2.0), which permits unrestricted use, distribution, and reproduction in any medium, provided the original work is properly cited.

\begin{abstract}
Background: The extracellular matrix can have a profound effect upon the phenotype of cancer cells. Previous work has shown that growth of bladder cancer cells on a matrix derived from normal basement membrane suppresses many malignant features that are displayed when the cells are grown on a matrix that has been modified by malignant tumors. This work was undertaken to investigate proteome-level changes as determined by a new commercially available proteome display involving 2-dimensional chromatography for bladder cancer cells grown on different extracellular matrix preparations that modulate the expression of the malignant phenotype.
\end{abstract}

Results: Depending on the matrix, between 1300 and 2000 distinct peaks were detected by two-dimensional chromatographic fractionation of $2.1-4.4 \mathrm{mg}$ of total cellular protein. The fractions eluting from the reversed-phase fractionation were suitable for mass spectrometric identification following only lyophilization and trypsin digestion and achieved approximately 10 -fold higher sensitivity than was obtained with gel-based separations. Abundant proteins that were unique to cells grown on one of the matrices were identified by mass spectrometry. Following concentration, peaks of $0.03 \mathrm{AU}$ provided unambiguous identification of protein components when $10 \%$ of the sample was analyzed, whereas peaks of $0.05 \mathrm{AU}$ was approximately the lower limit of detection when the entire sample was separated on a gel and ingel digestion was used. Although some fractions were homogeneous, others were not, and up to 3 proteins per fraction were identified. Strong evidence for post-translational modification of the unique proteins was noted. All I 3 of the unique proteins from cells grown on Matrigel were related to MYC pathway.

Conclusion: The system provides a viable alternative to 2-dimensional gel electrophoresis for proteomic display of biological systems. The findings suggest the importance of MYC to the malignant phenotype of bladder cancer cells. 


\section{Background}

The extracellular matrix (ECM) exerts major modulatory effects on the phenotype of both malignant and normal epithelial cells [1-5]. Malignant cells remodel the local ECM, which then becomes permissive for malignant growth $[6,7]$. In earlier reports from our laboratory we have developed a model for investigating the effect of ECM on cancer cells by growing them on ECM derived from normal tissue, from malignant tissue, and on plastic in conventional tissue culture where ECM effects are essentially absent $[8,9]$. Matrigel is a gel-forming basement membrane-derived ECM on which bladder cancer cells recapitulate their in vivo phenotype. In contrast, on SISgel, a gel-forming ECM product derived from normal porcine small intestine submucosa (SIS), the same bladder cancer cell lines display a much more normalized phenotype in which invasion is suppressed and the lowest grade cell line forms a multi-layered structure reminiscent of normal bladder epithelium. The mechanism for this effect is not known and may reflect protein-level changes not reflected in the transcriptome.

While 2-dimensional gel electrophoresis is a well-established method for investigating the proteome, a significant fraction of the proteome is not reflected in electrophoretograms [10]. The sensitivity is limited, large proteins do not even enter the gel, and the proteins must be purified away from the gel components for mass spectrometry. Two-dimensional chromatography is a relatively novel proteomic approach in which separation by pI and hydrophobicity achieves a proteome-level display $[11,12]$. We describe the application of 2-dimensional chromatographic proteomics to describing the effect of ECM on the phenotype of bladder cancer cells, including the mass spectrometric identification of some of the major differences in the proteomes of cells grown on Matrigel, SISgel and plastic.

\section{Methods}

\section{Cell culture}

J82 Transitional cell carcinoma cells were obtained from the American Type Culture Collection. (Bethesda, MD) and were grown as previously described $[8,9]$ on plastic, SISgel (Cook Biotech, W. Lafayette, IN) and Matrigel (BD Biosciences, Bedford, MA). Briefly, $0.8 \mathrm{ml}$ of ice cold Matrigel was layered onto polyethylene terephthalate membranes of 6-well cell culture inserts (Falcon, BectonDickinson Labware, Franklin Lakes, NJ). Gels were solidified at $37^{\circ} \mathrm{C}$. Ice cold SISgel, pH adjusted to $7.4(0.8 \mathrm{ml})$, was layered onto each membrane of the 6-well cell culture inserts and allowed to solidify overnight at $37^{\circ} \mathrm{C}$. Confluent cells growing on plastic were trypsinized with $1 \mathrm{ml}$ $0.25 \%$ trypsin; $1.0 \mathrm{mM}$ EDTA (Life Technologies). Trypsinized cells were resuspended in $2 \mathrm{ml}$ of respective media and 500,000 cells aliquoted onto solidified SISgel or Matrigel discs. Two ml of medium (Minimal Essential Media containing $1 \times$ nonessential amino acids, Lglutamine and pyruvate, Life Technologies, Rockville, MD) containing 1\% Fetal Calf Serum (Life Technologies) were layered beneath the transwell supports in 6-well plates such that an air bubble did not form. The cells were allowed to adhere to the gels for $72 \mathrm{hrs}$ before the media were replenished. Cultures were grown for 14 days with media changes twice per week. The fraction of cells growing under the above conditions are approximately $15 \%$ when cells growing on plastic are allowed to become nearly confluent [13]. Cells were harvested from SISgel with $1 \mathrm{ml}$ of $200 \mathrm{U} / \mathrm{ml}$ collagenase IV (Calbiochem, LaJolla, CA) following incubation at $37^{\circ} \mathrm{C}$ until the gel dissolved, approximately 1 hour. Cells were isolated from Matrigel with Matrisperse (BD Biosciences, San Jose, CA). The gels from 3 wells were removed and incubated with $30 \mathrm{ml}$ of Matrisperse with shaking on ice for $30 \mathrm{~min}$. The mixture was centrifuged, the supernatant was poured off and replaced by fresh Matrisperse until the process had been performed 3 times. After the final treatment, cells were centrifuged at $600 \times \mathrm{g}$ for $10 \mathrm{~min}$ and washed twice with cold PBS.

\section{Preparation of $\mathbf{8 2}$ cell lysates}

J82 cell cultures grown on plastic, Matrigel or SISgel were harvested and placed in a final volume $2.5 \mathrm{~mL}$ of lysisdenaturing buffer. The composition of the lysis-denaturing buffer was: $6 \mathrm{M}$ urea, $10 \%$ glycerol, $2 \mathrm{M}$ thiourea, 50 $\mathrm{mM}$ Tris- $\mathrm{HCl}\left(\mathrm{pH} 8.2\right.$ at $\left.10^{\circ} \mathrm{C}\right), 5 \mathrm{mM}$ Tris (2-carboxyethyl) phosphine hydrochloride, $2 \%(\mathrm{w} / \mathrm{v})$ n-octylglucoside and $1 \mathrm{mM}$ protease inhibitor cocktail (all components from Sigma-Alrich, St. Louis, MO). The samples were stored at $-80^{\circ} \mathrm{C}$ until processing. To lyse the cells, the samples were thawed and then vortexed for 30 sec. Next each cell lysate was centrifuged at $20,000 \times \mathrm{g}$ for $60 \mathrm{~min}$ at $18^{\circ} \mathrm{C}$. The each supernatant was removed and transferred into a PD10 column (Amersham Bioscience, Mountain View, CA), where the lysis buffer was exchanged with Protein Fractionation Start Buffer (Beckman Coulter, Inc., Fullerton, CA). Although the compositions of this buffer and the Elution Buffer (see below) are proprietary, similar formulations have been described [14]. The protein concentration was then determined by the bicinchoninic acid assay (MicroBCA, Pierce, Rockford, IL) with a DU800 spectrometer (Beckman Coulter, Inc.).

\section{Protein fractionation}

The proteins from the three samples were fractionated by pI and hydrophobicity with an automatic two-dimensional liquid chromatography system, the ProteomeLab ${ }^{\mathrm{TM}}$ PF 2D Protein Fractionation System (Beckman Coulter, Inc.). This is a commercial version of an instrument described previously $[11,14]$. The first dimension separated the Proteins are first separated by chromatofocusing 
(first dimension) followed by a second-dimension separation by reversed-phase chromatography.

In the first dimension, the chromatofocusing column (HPCF-1D column, $250 \times 2.1 \mathrm{~mm}$, Beckman Coulter) was used at ambient temperature with a flow rate of $0.2 \mathrm{ml} /$ $\mathrm{min}$. Before injection, the column was equilibrated with the Protein Fractionation Start Buffer (pH 8.5, BeckmanCoulter, Inc. Fullerton, CA) for $130 \mathrm{~min}$. The total mass of each sample type injected on the protein fractionation system was the following: $2.1 \mathrm{mg}$ for cells grown on plastic; $4.4 \mathrm{mg}$ for cells grown on SISgel; and $4.4 \mathrm{mg}$ for cells grown on Matrigel. The first-dimensional separation was started with the injection of sample, which began the execution of the following steps automatically. The start buffer was pumped through the column for the first 20 min to elute proteins with $\mathrm{pI}$ value above 8.5. After 20 min, the $\mathrm{pH}$ gradient from 8.5 to 4.0 was started by introduction of the Eluent Buffer (pH 4.0). After the end of the $\mathrm{pH}$ gradient (115 min), a $1 \mathrm{M}$ sodium chloride (Spectrum, Gardena, CA) solution was used to remove proteins with $\mathrm{pI}$ values below 4.0 from the column for $45 \mathrm{~min}$. The $\mathrm{pH}$ of the effluent from the first dimension column is monitored continuously with an in-line $\mathrm{pH}$ meter. Within the reproducibility of the $\mathrm{pH}$, it serves as a measurement of the fundamental molecular property of $\mathrm{pI}$ of eluted proteins. The final step was to rinse the column with water for 45 min. During the first-dimension separation, fractions were collected at every $0.3 \mathrm{pH}$ units during the $\mathrm{pH}$ gradient and at every 5 min when the pH value was constant. Both $\mathrm{pH}$ measurements and absorbance at $280 \mathrm{~nm}$ data were collected throughout the separation at a data rate of $1 \mathrm{~Hz}$. A total of 30 first-dimension fractions were collected over a 3 hour period. At the end of the first-dimension separation, the second dimension separation was started.

The second dimension used a high-performance, nonporous C-18 reversed-phase column with a flow rate of $0.75 \mathrm{ml} / \mathrm{min}$ at $50^{\circ} \mathrm{C}$ [15]. A gradient was formed using $0.1 \%$ trifluoroacetic acid (TFA; J.T. Baker Phillipsburg, NJ) in water and $0.08 \%$ TFA in acetonitrile (Burdick \& Jackson, Muskegon, MI). The gradient was $0-100 \%$ of $0.08 \%$ TFA in acetonitrile over $30 \mathrm{~min}$. The proteins were detected by absorbance at $214 \mathrm{~nm}$ with data collected at 5 $\mathrm{Hz}$. The first-dimension fractions were analyzed by injecting $200 \mu \mathrm{l}$ of each onto the second-dimension column. In mapping mode, second dimension fractions were not collected. The total time to run the first dimension fractions was about $48 \mathrm{~h}$. Selected first-dimension fractions were rerun, and fractions were collected at intervals of $15 \mathrm{sec}$., $187.5 \mu \mathrm{l}$, between 4-24 minutes of the run for subsequent mass spectrometry analysis. A total of 80 fractions was collected for each second-dimension separation. Chromatograms were visualized either with ProteoVue, which displays a single chromatogram, or DeltaVue, which allows comparison of two chromatograms. Both are provided by Beckman Coulter.

\section{Mass spectrometric analysis}

Peaks of interest were identified by examination of the proteomes of the 3 samples and selecting peaks that were unique to one sample. In order to afford the best chance for identifying proteins, the entire fraction was digested with sequencing grade modified trypsin (Promega, Madison, WI) at a 30:1 ratio of protein to trypsin using the integrated absorbance of the peak as a guide to protein content. The fractions were lyophilized to dryness prior to trypsinization. The proteins were dissolved in $100 \mu \mathrm{l}$ of 50 $\mathrm{mM} \mathrm{NH} \mathrm{NCO}_{3}$ followed by the appropriate volume of trypsin, and digestion was carried out overnight at $37^{\circ} \mathrm{C}$. After digestion, liquid was removed by SpeedVac (Savant Instruments, Farmingdale, NY), and the dried samples were stored at $-80^{\circ} \mathrm{C}$ until analysis. Each sample was dissolved in $10 \mu \mathrm{l}$ of $0.2 \%$ trifluoroacetic acid and purified with a reversed-phase ZipTip (Millipore, Billerica, MA) as recommended by the manufacturer. The eluted tryptic digest of a fraction $(0.5 \mu \mathrm{l})$ was mixed with $0.5 \mu \mathrm{l}$ of matrix solution $[2 \%(\mathrm{w} / \mathrm{v}) 2,5$-dihydroxybenzoic acid in $50 \%(\mathrm{v} / \mathrm{v})$ acetonitrile $/ 0.1 \%(\mathrm{v} / \mathrm{v})$ trifluoroacetic acid] and spotted on a stainless-steel MS sample plate. Peptide mass fingerprinting (PMF) analysis was performed by Voyager Elite MALDI-TOF MS (PerSeptive Biosystems, Framingham, USA). CID fragmentation of tryptic peptides was performed using MALDI-QIT-TOF MS (AXIMA QIT; Shimadzu/Kratos, Manchester, UK).

The peptide mass fingerprinting data were submitted to MASCOT peptide mass fingerprint program (Matrix Science, London, UK) [16] in order to obtain protein candidates for each fraction analyzed. Database searches were performed against the National Center for Biotechnology Information (NCBI) nonredundant database using the following parameters; (1) the protein database under Homo sapiens (2) unlimited protein molecular weight and pI ranges, (3) presence of protein modifications such as methionine oxidation, protein $\mathrm{N}$-terminus acetylation, and pyroglutamic acid, and (4) peptide mass tolerance of $\pm 0.25 \mathrm{Da}$. After matching experimental peptide mass values against predicted peptide masses of each entry in the database, MASCOT calculates the probability based MOWSE score that is a measure of the statistical significance of the first protein candidate, and scores $\geq 67$ represent $\mathrm{p}<0.05$ in the case of Human proteome. In order to confirm identities of protein candidates acquired in our peptide mass fragment analyses, the MS/MS data of several proteins were analyzed by MASCOT MS/MS ion search program (Matrix Science, London, UK). The database search parameters were the same as those used for peptide mass fragments except that a mass tolerance of \pm 0.5 Da was set for precursor ions and $\pm 2.0 \mathrm{Da}$ for frag- 
ment ions. We subjected 2-3 peptides per protein to MASCOT MS/MS ion search. We considered the confirmation to be positive when a significant MOWSE score $(\mathrm{p}<0.05)$ was generated (1) individually from all the peptide fragments analyzed or (2) from the combined MS/MS data of the peptides and (3) matching fragment sequences spanned the entire sequence of the intact protein chain, that is the matching sequences were not all found near one terminus or solely in the middle.

\section{Gel electrophoresis of fractions}

In order to compare the ease of PMF with LC/LC fractions as compared to analysis of gels, a set of peaks spanning the range of 0.2 to $0.025 \mathrm{AU}$ was selected. The entire fraction or fractions containing a peak ( 140 or $280 \mu \mathrm{L}$, if the peak was distributed into two fractions) was lyophilized and dissolved in $10 \mu \mathrm{L}$ of denaturing buffer. $1 \mu \mathrm{L}$ of diothiothreitol and $2.5 \mu \mathrm{L}$ of tracking dye were added and the entire volume was transferred to a $4-12 \%$ Tris-glycine gradient gel. Separation was at $90 \mathrm{~V}$ for $3 \mathrm{~h}$. followed by Coomassie Blue or silver staining (BioRad, Hercules, CA).

\section{Pathway analysis}

GenBank accession numbers for identified proteins were obtained via Entrez Gene [17]. Biologically relevant networks were assembled from genes identified on Matrigel, SISgel and plastic by using Ingenuity Pathways Analysis (IPA). This web-based application (Ingenuity Systems, [18]) enables the visualization and analysis of direct and indirect interactions among genes. Each gene identifier was mapped to its corresponding gene object in the Ingenuity Pathways Knowledge Base. Genes were not weighted by expression levels, and biological networks were built on this assumption.

\section{Results and discussion}

The proteomes of the J82 bladder cancer cells grown, on Matrigel, SISgel and on plastic in conventional tissue culture are displayed in Fig. 1. Although the actual data are in the form of chromatographic traces of absorbance at 214 $\mathrm{nm}$, for convenience in displaying and comparing chromatograms, a flat "gel-view" is used instead. Each "lane" corresponds to a first dimension fraction collected by $\mathrm{pH}$ and separated by reversed phase chromatography. Therefore the experimental $\mathrm{pI}$ of all proteins eluting within that fraction is specified experimentally by the $\mathrm{pH}$ range over which the fraction was collected. Retention time increases from bottom to top in this display. The absorbance of each peak is indicated by the intensity of the artificial band constructed by the software. To provide a comparison of the "gel view" and a conventional chromatographic display, one "lane" is also presented as an absorbance profile on the left. The "Lanes" are numbered from the most acidic to the most basic, which is the inverse of the actual elution order. The number of distinct peaks detected was
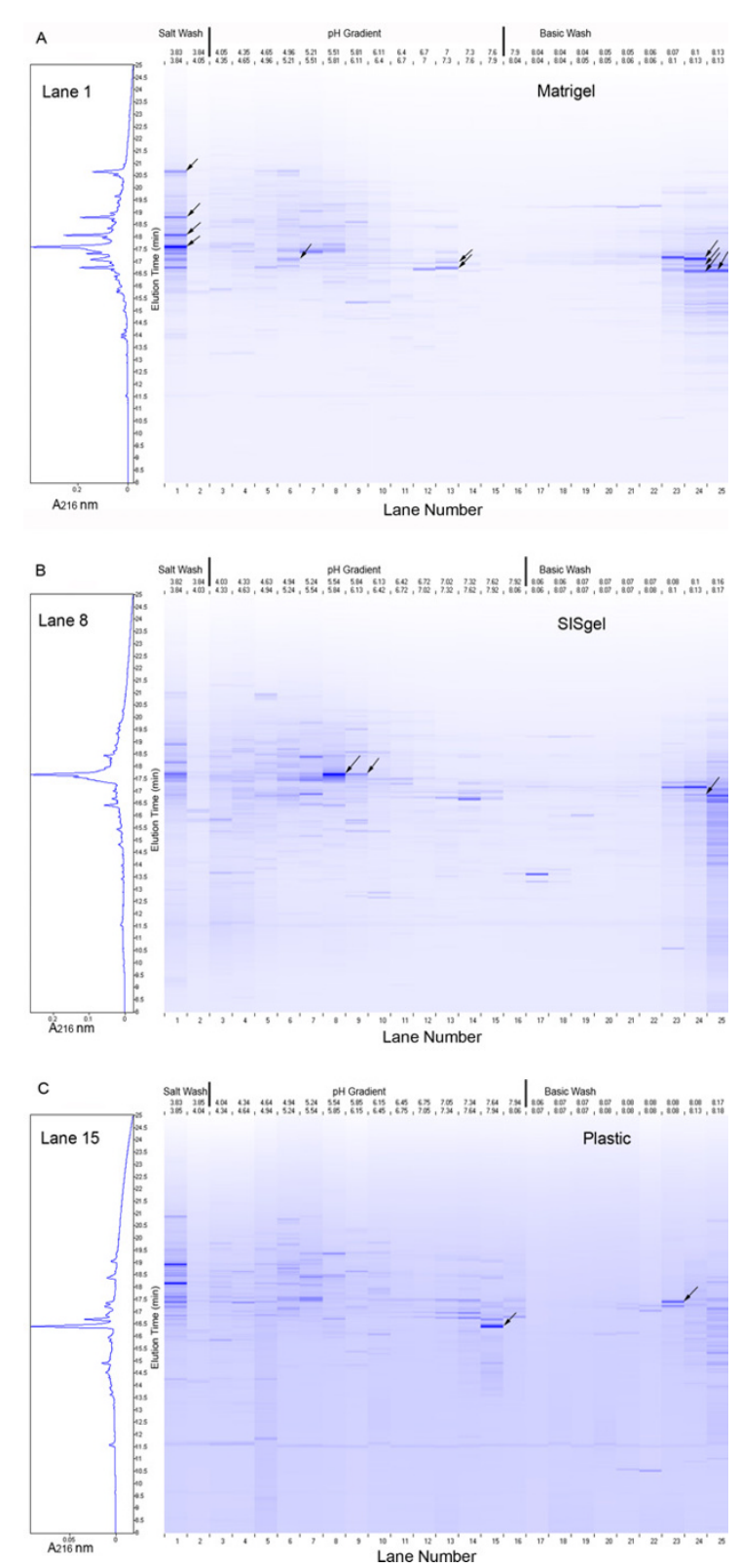

Figure I

"Gel-view" proteomic display of 182 cells cultured on Matrigel (A), SISgel (B) and plastic (C). Due to the current software configuration, the elution is from right to left, with lanes 17-25 showing proteins eluted during the base wash, lanes 2-16 showing proteins eluting during the $\mathrm{pH}$ 8.34.0 gradient, and lane I showing proteins eluting in the I.0 M $\mathrm{NaCl}$ wash. The $\mathrm{Y}$ axis shows the retention times of the second dimension between 10 and 24 minutes. The software presents the elution pattern as a simulated gel-view in which the color intensity is proportional to the absorbance. On the left of each display is shown a chromatographic view of one lane from which fractions were obtained for MS analysis presented as $A_{216}$ vs retention time. The black arrows identify fractions taken for MS analysis and reported in Table I. 
1345 from the cells grown on plastic, 1582 from the cells grown on Matrigel and 1984 from the cells grown on SISgel.

The display of the proteome falls into 3 regions. First is the basic wash, where the separation on the first dimension is by unknown parameters. Several peaks at the same retention time are seen in adjacent lanes, indicating the resolution of the first dimension separation above $\mathrm{pH} 8.3$ is probably minimal. Next is the region of the $\mathrm{pH}$ gradient, where the separations by pI are generally clear, as demonstrated by the presence of numerous bands. Some bands are observed with identical elution times in adjacent lanes, which may indicate the separation of fractions for the first dimension splits an individual protein between two fractions. Finally is the salt wash, which also presents a very complex set of fractions indicative of minimal separation in the first dimension.

The first step in further analysis was to identify some of the proteins represented in one of the samples but not in either of the other two. These unique components should be biologically the most interesting and would be expected to be enriched in post-translational modifications. The peaks selected for further analysis are indicated by the arrows. The proteins that could be identified to a confidence of $\mathrm{P}<0.05$ are listed in Table 1 . The proteins can be matched with the proteomic displays by the $\mathrm{pH}$ of the first dimension fraction (top of displays in Fig. 1) and retention time of the second dimension according to the arrows. All of the peaks selected yielded an identifiable protein with the exception of the abundant protein in lane 15 (plastic). Although the fraction provided a clear mass fragmentation, it did not match any known protein.

Clear differences in the proteomes are evident. In examining the fractions in which proteins have been identified, the cells growing in Matrigel express a number of chaperone molecules not seen in the other two samples. Additionally, because many of the proteins show experimental pI's different from the sequence pI, post-translational modification seems to represent a major theme in these uniquely expressed proteins. Because post-translational modification represents a major means of regulating pro-

Table I: Identification of several proteins unique to one or more samples. Only those for which a MOWSE score of $>65$ ( $p=0.05)$ for PMF or >34 $(p=0.05)$ for MS/MS and for which matching sequences spanned the entire sequence are reported. The experimental $p l$ is the measured $\mathrm{pH}$ value for the first dimension fraction. The \# Seq. Matched represents the number of fragments matching peptide sequences.

\begin{tabular}{|c|c|c|c|c|c|c|c|}
\hline Exp. pl & $\begin{array}{l}\text { RT } \text { 2nd Dim. }^{\text {nd }} \text { (min) }\end{array}$ & Gene Symbol & $\begin{array}{c}\mathrm{NCBI} \\
\text { Accession } \\
\text { Number }\end{array}$ & $\begin{array}{c}\text { Sequence MWI } \\
\mathrm{pl}\end{array}$ & $\begin{array}{l}\text { MOWSE Score } \\
\text { (PMF) }\end{array}$ & $\begin{array}{l}\text { Coverage \% (\# } \\
\text { Seq. Matched) }\end{array}$ & $\begin{array}{c}\text { MOWSE Score } \\
\text { (MS/MS) }\end{array}$ \\
\hline \multicolumn{8}{|c|}{ Cells grown on Matrigel } \\
\hline$<4.0$ & 17.560 & $\begin{array}{l}\text { ER60 HSPA5 } \\
\text { VIME }\end{array}$ & $\begin{array}{c}2245365 \\
16507237 \\
37852\end{array}$ & $\begin{array}{l}57245 / 5.88 \\
72431 / 5.07 \\
53724 / 5.06\end{array}$ & 816886 & $\begin{array}{c}29(13) 23(11) \\
28(13)\end{array}$ & 94 \\
\hline$<4.0$ & 18.027 & HSPA5 & 16507237 & $7243 \mid / 5.07$ & 120 & $29(17)$ & \\
\hline$<4.0$ & 18.777 & $\begin{array}{l}\text { HSPA8 HSPA5 } \\
\text { ENOA }\end{array}$ & $\begin{array}{c}24234686 \\
16507237 \\
1167843\end{array}$ & $\begin{array}{l}53626 / 5.62 \\
72431 / 5.07 \\
47566 / 7.01\end{array}$ & 10313696 & $\begin{array}{c}25(7) 22(11) \\
17(8)\end{array}$ & 4136 \\
\hline$<4.0$ & 20.687 & HSP60 & 49522865 & $61229 / 5.7 \mid$ & 99 & $20(8)$ & 93 \\
\hline $4.63-4.94$ & 17.167 & ATM & |49793| & $356785 / 6.37$ & 74 & $9(19)$ & \\
\hline $7.02-7.32$ & 16.740 & H2B.I & $|56855|$ & $13928 / 10.3$ & 106 & $57(9)$ & 48 \\
\hline $7.02-7.32$ & 16.998 & RPL9 RPSI8 & $\begin{array}{l}13278765 \\
75517910\end{array}$ & $\begin{array}{l}21992 / 9.96 \\
17708 / 11.0\end{array}$ & 10173 & $53(8) 38(9)$ & 7844 \\
\hline$>8.3$ & 16.597 & APC & 68533057 & $314407 / 8.03$ & 70 & $9(18)$ & \\
\hline$>8.3$ & 16.687 & ALDOA & 4557305 & $39964 / 8.33$ & 70 & $26(7)$ & 46 \\
\hline$>8.3$ & 17.094 & GAPDH & 31645 & $36244 / 8.26$ & 191 & $66(16)$ & 64 \\
\hline$>8.3$ & 16.634 & $\begin{array}{l}\text { RUVBL/ } \\
\text { CHTFI8 }\end{array}$ & 14336725 & $|30269 / 9.5|$ & 72 & $16(13)$ & \\
\hline \multicolumn{8}{|c|}{ Cells grown on SISgel } \\
\hline$>8.3$ & 16.774 & RSNL2 & 48257203 & $60839 / 9.07$ & 70 & $23(\mathrm{II})$ & \\
\hline $5.54-5.84$ & 17.667 & AKRIBI ATPB & $\begin{array}{c}\mid 3529257 \\
2893 \mid\end{array}$ & $\begin{array}{l}36298 / 6.82 \\
34026 / 4.90\end{array}$ & 15596 & $49(14) 25(6)$ & 7459 \\
\hline $5.54-5.84$ & 17.695 & AKRIBI ATPB & $\begin{array}{c}\mid 3529257 \\
2893 \mid\end{array}$ & $\begin{array}{l}36298 / 6.82 \\
34026 / 4.90\end{array}$ & 16690 & $48(17) 28(7)$ & 6879 \\
\hline $5.94-6.13$ & 17.667 & AKRIBI ATPB & $\begin{array}{c}\mid 3529257 \\
2893 \mid\end{array}$ & $\begin{array}{l}36298 / 6.82 \\
34026 / 4.90\end{array}$ & 9848 & $55(13) 22(3)$ & 51 \\
\hline \multicolumn{8}{|c|}{ Cells grown on plastic } \\
\hline$>8.3$ & 17.407 & GAPDH & $31645^{\circ}$ & $36244 / 8.26$ & 192 & $56(16)$ & 68 \\
\hline
\end{tabular}


teins, these are likely to be key molecules related to the difference in phenotype. Of interest is the identification of glyceraldehydes 3-phosphate dehydrogenase (GAPDH) at a different retention in the second dimension separation. This is not an artifact, as is shown in Fig. 2, which compares the second dimension separations of the basic $\mathrm{pH}$ fractions, Lanes 23 and 24, that eluted before the pH gradient, from the cells grown on plastic and Matrigel. Lanes 23 and 24 from Matrigel both contain a large peak eluting at $17.094 \mathrm{~min}$ that was identified as GAPDH (green trace), On plastic the cells also expressed a different form that eluted at $17.407 \mathrm{~min}$ and corresponded to a small peak in the proteome expressed in Matrigel. The difference in retention time, $0.313 \mathrm{~min}(18.7 \mathrm{sec})$, is significant. In cells grown on SISgel, the peak was not seen in Lane 23. However, two peaks corresponding to the adjacent peaks seen in the Lane 24 from cells grown on plastic were seen, except that the height of the peak with the $17.094 \mathrm{~min}$ retention time was higher than the one eluting at 17.407 min that was identified by MS. These results also indicate that the resolution of proteins in the first dimension at $>\mathrm{pH} 8.3$ is less than in the $\mathrm{pH}$ gradient.

Of particular interest was the finding of two, very large proteins with sequence molecular weights exceeding 300 $\mathrm{KDa}$. The peptide mass fingerprints of these proteins are shown in Fig. 3. The proteins were identified as APC (2843 aa) and ATM (3066 aa). As is seen from the fragments identified, the entire protein sequence was spanned, which argues against the proteins being proteolytically cleaved fragments of lower molecular weight.

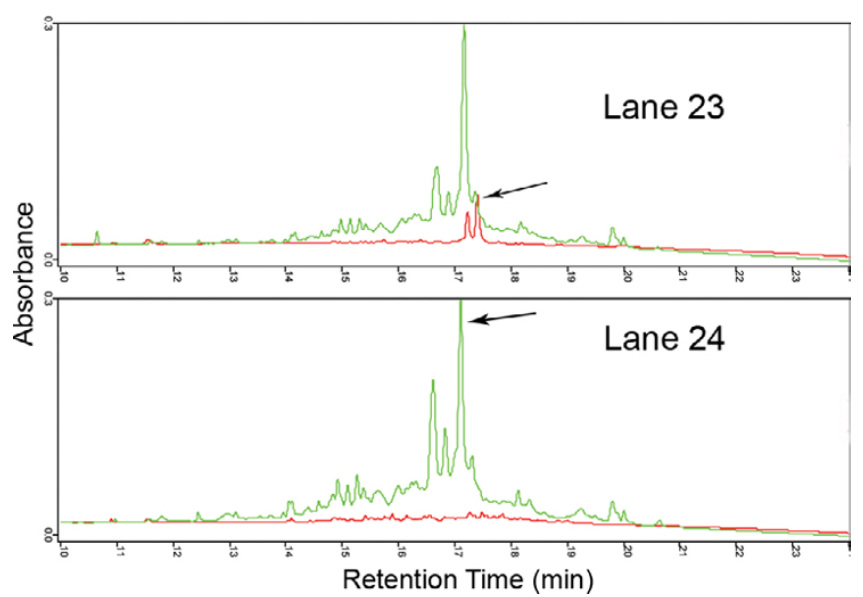

Figure 2

DeltaVue comparison of $2^{\text {nd }}$ dimension fractionations of basic first dimension fractions fractions. Lane 24 and Lane 23 showing different properties of glyceraldehyde 3-phosphate dehydrogenase in cells grown on plastic and on Matrigel. The arrows indicate the identified proteins. Green = cells grown on Matrigel, Red = cells grown on plastic.
The reproducibility of separations was also evaluated by comparing the fractionation of two separate protein preparations made at different times and run about 3 months apart, as shown in Fig. 4. Because the pH gradient had been modified slightly, no two fractions showed identical pI ranges. However, one pair showed only an $0.02 \mathrm{pH}$ unit difference. The retention times of the main peaks were reproducible to within \pm 5 seconds in the second dimension. The ratios of some peaks were reversed, presumably reflecting biological variability in those proteins, although all the peaks will require identification in order to demonstrate this more clearly. The presence and absence of some peaks could be due to the small difference $\mathrm{pH}$ ranges included. The number of peaks counted in different fractions analyzed 3 months apart was virtually identical, in spite of a difference in the amount of material injected. The total number of peaks observed in cells grown on Matrigel was 1582 (4.4 mg protein) vs 1525 (2.9 mg protein) and 1999 (4.4 mg protein) vs 1984 (2.9 mg protein) for cells grown on SISgel in samples run 3 months apart.

One potential advantage of the chromatographic approach is that the fractions are presented in liquid with a simple solvent, as opposed to a within a gel. We attempted a preliminary comparison of sensitivity of gelbased and chromatographic fractionation methods. We selected a series of peaks of different peak heights ranging from about $0.2 \mathrm{AU}$ in size down to $0.025 \mathrm{AU}$. In general, only peaks with heights of $0.1 \mathrm{AU}$ or more showed any discernible bands on polyacrylamide electrophoresis when stained with Coomassie Blue. Very faint bands with silver stain were discernible down to about $0.05 \mathrm{AU}$ analyzing the entire sample. The results of peptide mass fingerprinting of five such randomly selected fractions selected from cells grown on plastic are summarized in Table 2. As shown in Table 2, proteins forming small peaks in the range of $0.025 \mathrm{AU}$ are easily identifiable using about $10 \%$ of the fraction.

As with all proteomics techniques, however, more than a single protein was sometimes found in the fractions as collected, particularly those collected in the basic and salt wash regions. In part this reflected that the time-collected fraction width was greater than the width of homogeneous protein peaks and that some peaks do represent unresolved proteins. The option of collecting by automated peak detection would be helpful. The resolution of proteins is optimal in the $\mathrm{pH}$ gradient. The fractions eluting before and after the gradient are more complex, and the principles of separation on the chromatofocusing column in these regions are not completely understood $[11,12,14,19]$. However, given that $90 \%$ of the sample remains after MS, the possibility of a third dimension such as separation by molecular weight on gels, by LC 

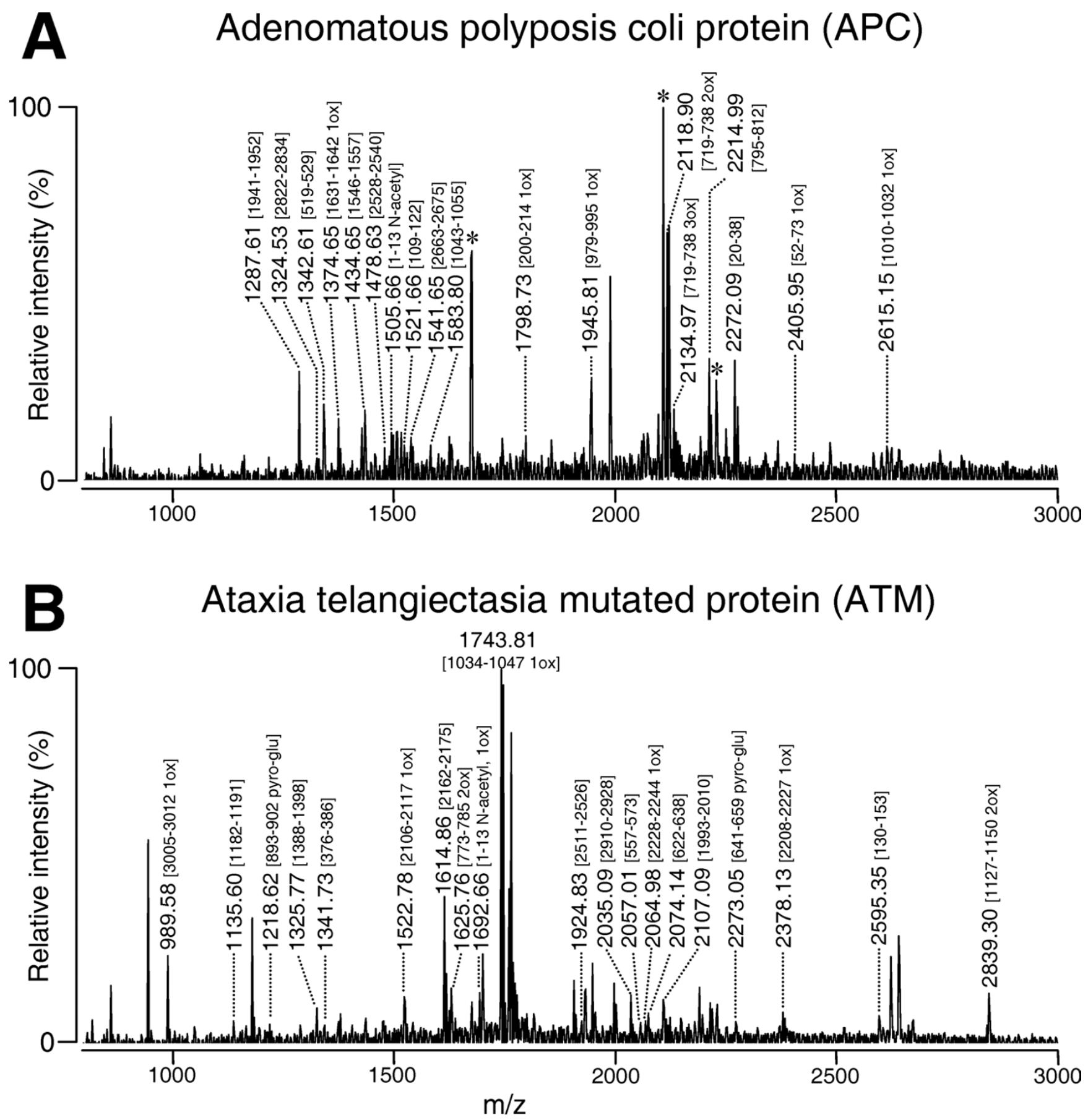

Figure 3

Peptide mass fingerprinting of APC and ATM proteins. Fragments matching sequences in the protein are indicated along with the amino acid numbers. Note that sequences from the entire protein are matched, indicating that the intact protein is identified. The peaks marked with an asterisk in A. match Aldolase A, which elutes 0.09 min later than APC. The unassigned peaks in ATM do not match a single protein.

$[12,19,20]$, or even by MS [21] is certainly feasible if further resolution is needed. In addition, the possibility of
MALDI-TOF on the intact protein is feasible, thereby allowing identification of the intact molecular weight. 


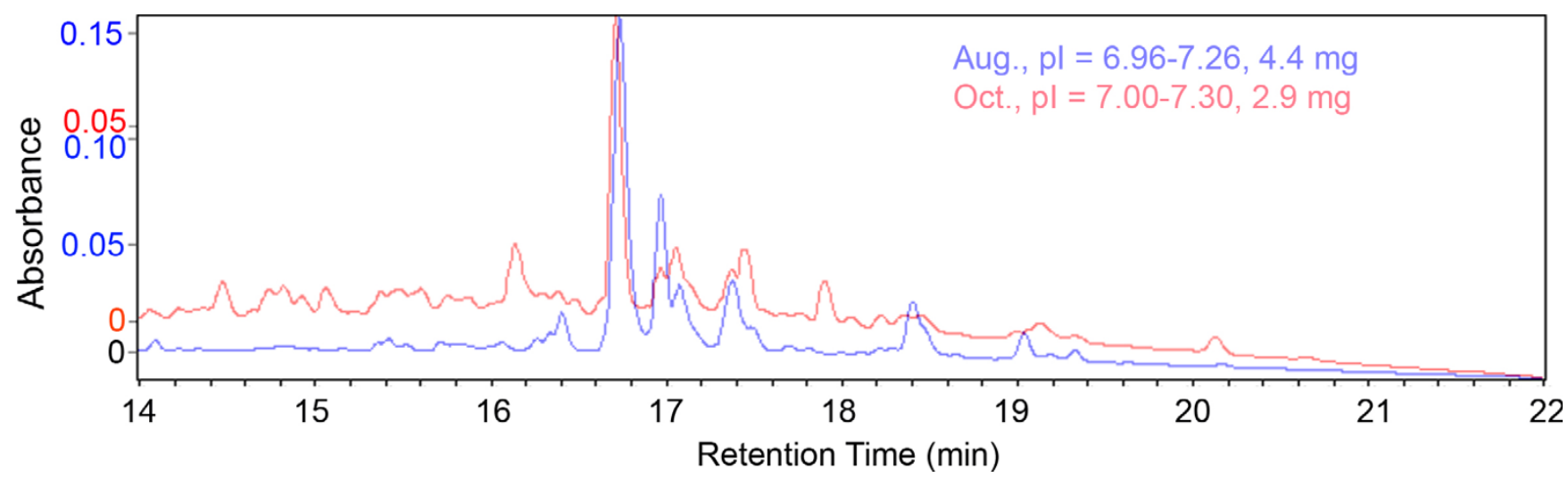

Figure 4

Reproducibility of separations on the PF2D system. Equivalent first dimension fractions of separate cultures grown on Matrigel analyzed approximately 3 months apart. The peak heights were normalized to the same relative size to show the similarities in shape. The actual absorbances are shown on the left, color-coded.

Pathway analysis of the proteins identified in Table 1 yielded several interesting findings. Of the 13 proteins that were uniquely found in Matrigel, all 13 , including GAPDH, fit into a pathway involving MYC, as shown in Fig. 6. Although GAPDH is thought to be a simple glycolytic enzyme and "housekeeping gene" [22], it is involved in telomere shortening and may have other signaling roles as well [23]. This protein apparently bears different post translational modifications in cells grown on plastic and Matrigel. The MYC pathway also was recently identified as playing a key role in suppression of the malignant phenotype [24]. Based on the pI being much less than the pI calculated from the sequence, the histone H2B.1 protein likely was post-translationally modified in cells growing on Matrigel. Interestingly, although the other histones of the chromatin complex were reported to be phosphorylated and acetylated in K562 erythroleukemia cells, H2B was not [25]. On SISgel, only two unique proteins were identified (Table 1). That many of the unique proteins identified in cells grown on Matrigel fit into one network reinforces the suggestion made above that they are key players in regulating the phenotype, and that post-translational modification plays a major role in regulating the phenotype. Further identification of proteins that are dif- ferentially expressed among the three growth conditions will be required to fill in these pathways.

These preliminary findings support our hypothesis that the malignant phenotype is suppressed on SISgel. The two ribosomal proteins and the glycolytic enzymes aldolase and enolase found in cells grown on Matrigel most likely reflect the higher level of protein translation and glycolysis by malignant cells, whereas several others are associated with malignant functions. Interestingly, although aldolase reductase appears to be a metabolic enzyme, it also functions as a signaling molecule. In endothelial cells it has been reported to regulate TNF signaling and to upregulate cell adhesion molecules on the cell surface [26], a function that is consistent with a less malignant phenotype. Further work will require identifying a larger number of proteins in the fractions and assembling a picture of the pathways involved in the biology.

\section{Conclusion}

Part of the power of the proteomics approach in general is that it is sensitive to post-translational modifications that represent the most important means of biologically modulating the activities of proteins involved in signaling

Table 2: Identification of proteins as a function of peak height using in solution digestion. The lower MOWSE scores reflect the low molecular weights of two of the proteins and their most probable identification as antibody fragments.

\begin{tabular}{clccc}
\hline Peak Ht (AU) & $\begin{array}{l}\text { Gene Symbol and NCBI } \\
\text { Accession No. }\end{array}$ & Seq. M/pl & MOWSE Score & Coverage\% (Seq. Matched) \\
\hline 0.206 & GPPI30 2145095 & $81902 / 4.73$ & 67 & $19(10)$ \\
0.114 & VH4VD 563413 & $9534 / 9.17$ & 51 & $71(4)$ \\
0.083 & VH4VDJ II45246 & $14616 / 5.58$ & 56 & $61(5)$ \\
0.049 & PI3K 2143260 & $192677 / 8.24$ & 62 & $10(12)$ \\
0.025 & KRTI7 21754583 & $40577 / 4.90$ & 70 & $30(10)$ \\
\hline
\end{tabular}




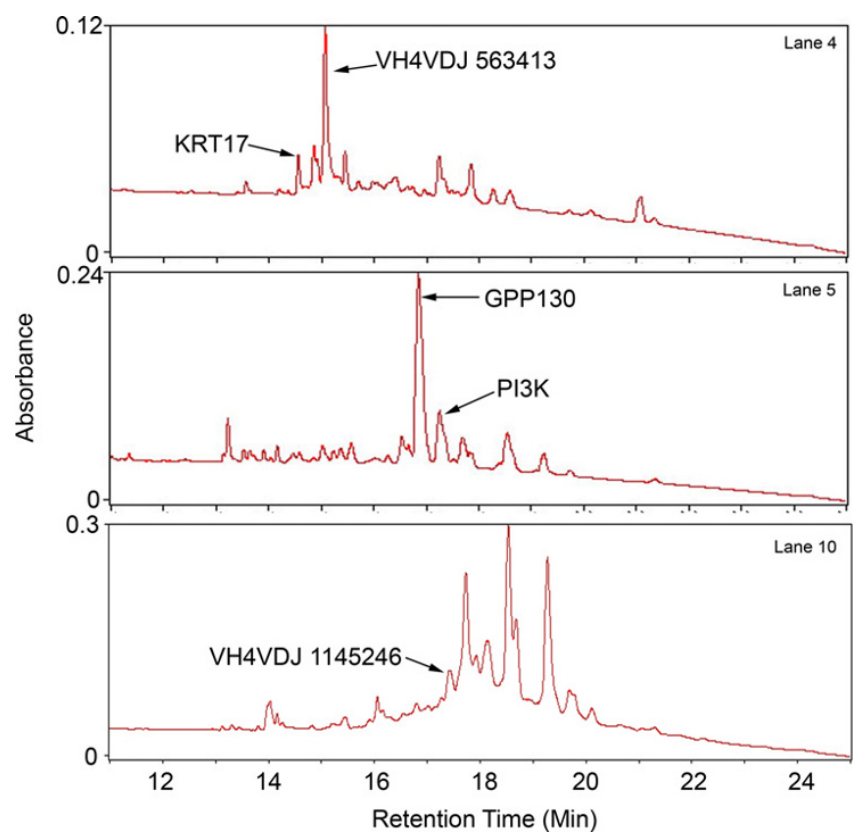

Figure 5

Selection of peaks of different sizes from $J 82$ cells growing on plastic identified in Table 2.

pathways. Microarray techniques yield no information concerning protein modification and are silent concerning changes in protein concentration that are not associated with altered transcription. The differences in the actual pI and the sequence pI shown in Table 1 strongly suggests that some of these unique peaks may represent post-translational modifications that shift the chromatographic properties of particular proteins. The selection of proteins on the basis of being expressed uniquely in one sample is likely to be highly represented in post-translationally modified proteins. Chaperone-type proteins were up-regulated in the cells growing on Matrigel. Glyceraldehyde 3-phosphate dehydrogenase is apparently posttranslationally modified in a different way, depending upon the matrix on which the cells are grown. Pathway analysis of the unique proteins showed that all those identified in cells grown on Matrigel fit into a pathway involving MYC. Those uniquely expressed on SISgel and plastic also suggested signaling pathways. Future work to identify all the differentially expressed proteins should shed further light on these pathways. As a tool for biological investigation, this system provides several advantages. The system is reproducible with respect to retention time and one parameter $(\mathrm{pI})$ is a fundamental molecular property that is measured. In addition, as shown by finding large proteins such as APC (311 KDa) and ATM (357 KDa) the upper limit imposed by the necessity of entering a gel does not appear to be operant with chromatographic display. Third, the sensitivity with respect to MS identification using in solution digestion is excellent, and even small peaks (0.03 AU) are readily identifiable without loss in retrieving from a gel. The main limit to reproducibility appears to lie in the chromatofocusing, not the reversed phase separation. Resolution was highest in the fractions eluted during the $\mathrm{pH}$ gradient as opposed to those eluting during the $\mathrm{pH} 8.3$ and salt washes.

\section{Abbreviations \\ AU: absorbance units}

ECM: extracellular matrix

LC: liquid chromatography

MALDI-TOF: Matrix Assisted Laser Desorption/Ionization-Time Of Flight

MS: mass spectrometry

SIS: small intestine submucosa

\section{Competing interests}

Dr. Hurst has a grant from Beckman Coulter, Inc. to support work using the PF2D instrument. Other than this, the authors declare that they have no competing interests.

\section{Contributions of authors}

REH conceived the study, performed most of the data analysis and wrote the paper. KDK grew the cells and verified their phenotypes. MD performed Ingenuity Pathway Analysis and helped to finalize figures and the manuscript. NT and AS performed the mass spectrometric analyses and provided interpretations under the direction of HM, who also helped with the writing of the manuscript. RS helped with the pathway analysis and interpretation of networks. EB performed the PF2D analyses under the direction of MS, who assisted with the interpretation of the protein separations and assisted with the writing of the paper.

\section{Acknowledgements}

This work was supported by CA 75322 and DK 069808 and by a grant from Beckman Coulter (REH) and by EYI3877 \& EY06595 (HM). Beckman Coulter reviewed the manuscript to insure no proprietary information was disclosed but otherwise played no role in publication.

\section{References}

I. Wheelock MJ, Johnson KR: Cadherins as modulators of cellular phenotype. Annu Rev Cell Dev Biol 2003, 19:207-235.

2. Arnold JT, Lessey BA, Seppala M, Kaufman DG: Effect of Normal Endometrial Stroma on Growth and Differentiation in Ishikawa Endometrial Adenocarcinoma Cells. Cancer Res 2002, 62:79-88

3. Booth C, Harnden P, Selby PJ, Southgate J: Towards defining roles and relationships for tenascin- $C$ and TGFbeta- $I$ in the normal and neoplastic urinary bladder. J Pathol 2002, 198:359-368.

4. Shekhar MP, Werdell J, Santner SJ, Pauley RJ, Tait L: Breast stroma plays a dominant regulatory role in breast epithelial growth 

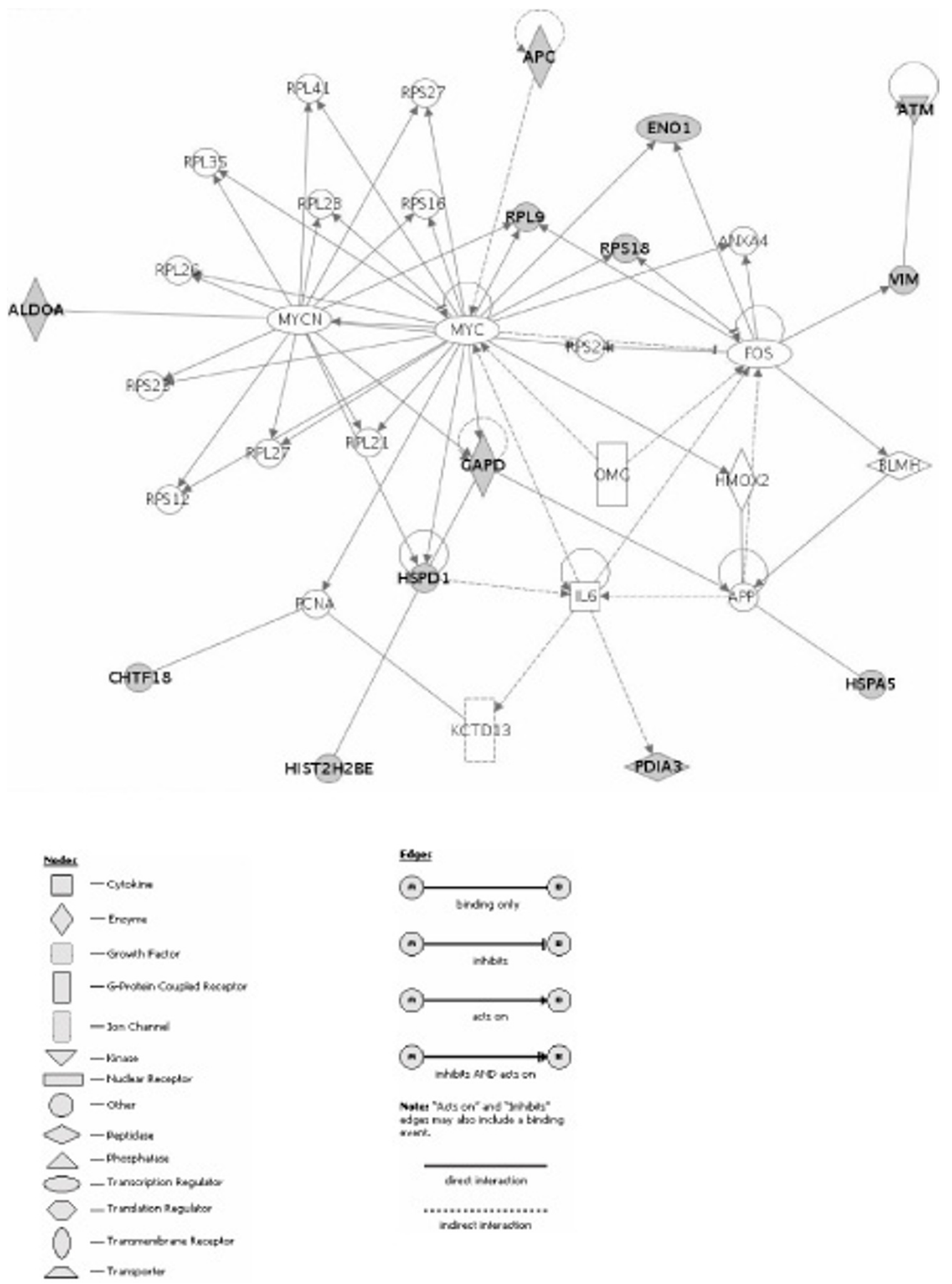

Figure 6

Genes and relevant networks for Matrigel. Focus gene/protein identifiers displayed as bold text. Proteins that were identified in samples are shown in gray color. 
and differentiation: implications for tumor development and progression. Cancer Res 200I, 6I:1320-1326.

5. Smith BA, Kennedy WJ, Harnden P, Selby PJ, Trejdosiewicz LK, Southgate J: Identification of genes involved in human urothelial cell-matrix interactions: implications for the progression pathways of malignant urothelium. Cancer Res 200I, 6I:1678-1685

6. Tuxhorn JA, Ayala GE, Smith MJ, Smith VC, Dang TD, Rowley DR: Reactive stroma in human prostate cancer: induction of myofibroblast phenotype and extracellular matrix remodeling. Clin Cancer Res 2002, 8:29/2-2923.

7. Deryugina El, Bourdon MA, Reisfeld RA, Strongin A: Remodeling of collagen matrix by human tumor cells requires activation and cell surface association of matrix metalloproteinase-2. Cancer Res 1998, 58:3743-3750.

8. Hurst RE, Kyker KD, Bonner RB, Bowditch RG, Hemstreet GP: Matrix-Dependent Plasticity of the Malignant Phenotype of Bladder Cancer Cells. Anticancer Res 2003, 23:3 | |9-3। 28.

9. Kyker KD, Culkin DJ, Hurst RE: A model for 3-dimensional growth of bladder cancers to study mechanisms of phenotypic expression. Urologic Oncology 2003, $21: 255-261$.

10. Graham DR, Elliott ST, Van Eyk JE: Broad-based proteomic strategies: a practical guide to proteomics and functional screening. J Physiol 2005, 563:I-9.

II. Lubman DM, Kachman MT, Wang H, Gong S, Yan F, Hamler RL, O'Neil KA, Zhu K, Buchanan NS, Barder TJ: Two-dimensional liquid separations-mass mapping of proteins from human cancer cell lysates. J Chromatogr B Analyt Technol Biomed Life Sci 2002 782: $183-196$.

12. Wang H, Kachman MT, Schwartz DR, Cho KR, Lubman DM: A protein molecular weight map of ES2 clear cell ovarian carcinoma cells using a two-dimensional liquid separations/mass mapping technique. Electrophoresis 2003, 23:3168-3I8I.

13. Hurst RE, Kamat CD, Kyker KD, Green DE, Ihnat MA: A nove multidrug resistance phenotype of bladder tumor cells grown on Matrigel or SIS gel. Cancer Lett 2005, 2 17:17|-180.

14. Zheng S, Schneider KA, Barder T], Lubman DM: Two-dimensional liquid chromatography protein expression mapping for differential proteomic analysis of normal and O157:H7 Escherichia coli. Biotechniques 2003, 35:1202-1212.

15. Paasch BD, Lin YS, Porter S, Modi NB, Barder TJ: Determination of Ro 48-3656 in rat plasma by reversed-phase high-performance liquid chromatography. Comparison of 1.5 -microm nonporous silica to 3.5 -microm porous silica analytical columns. J Chromatogr B Biomed Sci Appl 1997, 704:23I-242.

16. Perkins DN, Pappin DJ, Creasy DM, Cottrell JS: Probability-based protein identification by searching sequence databases using mass spectrometry data. Electrophoresis 1999, 20:355I-3567.

17. Entrez Gene [http://www.ncbi.nlm.nih.gov/entrez/ query.fcgi? $\mathrm{db}=$ gene\&cmd=Retrieve\&dopt $=$ full report\&list uids $=942$ I]

18. Ingenuity Systems [http://www.ingenuity.com/]

19. Yan F, Subramanian B, Nakeff A, Barder T], Parus S], Lubman DM: A comparison of drug-treated and untreated HCT- I 16 human colon adenocarcinoma cells using a 2 -D liquid separation mapping method based upon chromatofocusing PI fractionation. Anal Chem 2003, 75:2299-2308.

20. Chong BE, Yan F, Lubman DM, Miller FR: Chromatofocusing nonporous reversed-phase high-performance liquid chromatography/electrospray ionization time-of-flight mass spectrometry of proteins from human breast cancer whole cell lysates: a novel two-dimensional liquid chromatography/ mass spectrometry method. Rapid Commun Mass Spectrom 2003, 15:29|-296.

21. Wall DB, Parus SJ, Lubman DM: Three-dimensional protein map according to pl, hydrophobicity and molecular mass. J Chromatogr B Analyt Technol Biomed Life Sci 2002, 774:53-58.

22. Thellin O, Zorzi W, Lakaye B, De BB, Coumans B, Hennen G, Grisar $T$, lgout $A$, Heinen $E$ : Housekeeping genes as internal standards: use and limits. J Biotechnol 1999, 75:29|-295.

23. Sundararaj KP, Wood RE, Ponnusamy S, Salas AM, Szulc Z, Bielawska A, Obeid LM, Hannun YA, Ogretmen B: Rapid shortening of telomere length in response to ceramide involves the inhibition of telomere binding activity of nuclear glyceraldehyde-3. phosphate dehydrogenase. J Biol Chem 2004, 279:6I52-6I 62.
24. Dozmorov MG, Kyker KD, Saban R, Knowlton N, Dozmorov IM, Centola M, Hurst RE: Analysis of the Interaction of Extracellular Matrix and Phenotype of Bladder Cancer Cells. BMC Cancer 2006, 6: 12.

25. Galasinski SC, Louie DF, Gloor KK, Resing KA, Ahn NG: Global regulation of post-translational modifications on core histones I. J Biol Chem 2002, 277:2579-2588.

26. Ramana KV, Bhatnagar A, Srivastava SK: Inhibition of aldose reductase attenuates TNF-alpha-induced expression of adhesion molecules in endothelial cells. FASEB J 2004, 18: $1209-1218$.

Publish with Bio Med Central and every scientist can read your work free of charge

"BioMed Central will be the most significant development for disseminating the results of biomedical research in our lifetime. "

Sir Paul Nurse, Cancer Research UK

Your research papers will be:

- available free of charge to the entire biomedical community

- peer reviewed and published immediately upon acceptance

- cited in PubMed and archived on PubMed Central

- yours - you keep the copyright 